\title{
Census of seabird colonies on Nordaustlandet, Svalbard, and in neighbouring localities in 1978 and 1979
}

\author{
PALLE UHD JEPSEN AND ARE MOBAK
}

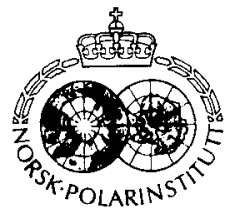

\begin{abstract}
Jepsen, P. U. \& Mobæk, A. 1983: Census of seabird colonies on Nordaustlandet, Svalbard, and in neighbouring localities in 1978 and 1979. Polar Research 1 n.s. . 199-209.

Seabird colonies were censused during the summer expedition of Norsk Polarinstitutt to Nordaustlandet. Svalbard, in 1978 and 1979, and to Kongsøya in 1979. An outline is given of the distribution of the species together with an estimate of the number of breeding pairs in the colonies. Twenty-five colonies were censused; seven were visited both years. Four colonies with more than 1,000 breeding pairs of the most abundant species, Brünnich's guillemot and kittiwake, were found on Nordaustlandet.
\end{abstract}

Palle Uhd Jepsen, Vildtreservatkontoret, 8410 Rønde, Denmark: Are Mobak, Fylkesmannen i Hedmark, Hedmark Fylkeshus, 2300 Hamar. Norway; October 1981 (revised June 1983).

\section{Introduction}

The seabird colonies in Spitsbergen, particularly those in the western fjords and on Prins Karls Forland, have been investigated and described by Løvenskiold (1964), Larsen (1965), and Norderhaug $(1967,1974)$. Norderhaug et al. (1977) mention that seabird colonies of more than 1,000 breeding pairs are unlikely on Nordaustlandet. They also state that colonies of between 1,000 and 10,000 birds have been registered by Løvenskiold (1964) among others on the islands and coasts of Hinlopen. A single colony on Alkefjellet had more than 100,000 birds. On Kong Karls Land, between 1,000 and 10,000 seabirds have been registered in two colonies. Not until lately, in connection with the summer expeditions of Norsk Polarinstitutt (NP), have quantitative and qualitative data been collected from the seabird colonies on Nordaustlandet, the surrounding islands, and on Kong Karls Land.

Two biologists joined the NP summer expeditions in 1978 and 1979 to census breeding species in seabird colonies in northeastern Svalbard. The results of these registrations are presented in this report.

The breeding conditions of the following seabirds are described: fulmar Fulmarus glacialis, kittiwake Rissa tridactyla, little auk Alle alle, Brünnich's guillemot Uria lomvia, puffin Frarercula arctica, and black guillemot Cepphus grylle. The breeding occurrence of glaucous gulls
Larus hyperboreus and ivory gulls Pagophila eburnea is also described.

Leaders of the ornithological programme were Are Mobæk in 1978 and Palle Uhd Jepsen in 1979, with assistants Per Magne Jensen and Hakon Robak, respectively. The authors are grateful for their efforts and cooperation throughout the programme. Thanks are also due to participants on other projects for a number of observations which form part of the material for this report.

\section{Material and methods}

\section{The study area}

The investigated seabird colonies are found on localities possible to visit within the limits which had to be expected, as the foremost aim of the expedition was within topographic and geologic investigations.

The different routes taken by the expedition vessel m/s 'Norvarg' in 1978 and 1979, and weather conditions made it impossible to census all the same colonies in 1979 as in 1978. But a large area was covered and seabird colonies not visited before were registered both years. The study areas in 1978 and 1979 are shown in Fig. 1.

Observations in 1978 were made mainly in the northwestern part of Nordaustlandet, along the 


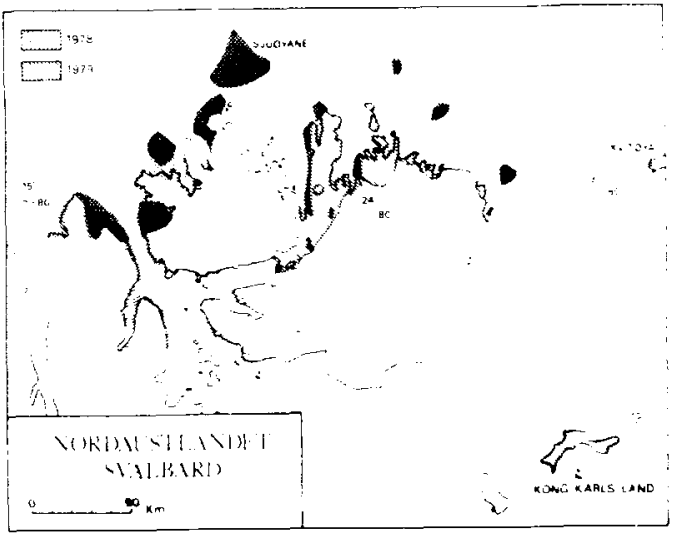

Fig. 1. Map of survey area in 1978 and 1979. The large inland localities for 1979 were surveyed mainly from a helicopter.

west side of Hinlopen. The following seabird colonies were registered:

Nordkapp. 24 July

Vesle Tavleøya. 26 July
Geren, Lomfjorden, 28 July

Kapp Fanshawe and Alkefjellet, 29 July

Selanderneset. 31 July

Martensøya and Nelsonøya, 4 August

Hamiltonbukta, 8 August

Depotodden and Goosbukta, 9 August

Waldenøva. 11 August

Karl XII Øyane, 12 August

Foynøya and Brochøya, 27 August

The 1979 registrations included some of the localities visited in 1978 (Tables 1 and 2), but in addition included Kongsøya in Kong Karls Land, and localities in the northeastern part of Nordaustlandet. The following localities for seabird colonies were registered:

Mosselbukta, 26 July

Depotodden, 2 August and 8 August

Martensøya, Parryøya, Phippsøya, Nordkapp. and Waldenøya, 8 August

Foynøya and Brochøya, 18 August

Table 1. Shematic outline of localities registered. L - from the shore. $G$ - from rubber dinghy, E-from the expedition vcssel, $\mathrm{H}$ - from helicopter. ' $\mathrm{I}$ ' shows that time (number of hours) has not been the limiting factor for accomplishing the counts, and 'd' indicates that available time was not sufficient for complete registrations.

\begin{tabular}{|c|c|c|c|c|c|c|c|c|c|}
\hline \multirow[b]{2}{*}{ Localities } & \multicolumn{4}{|c|}{1978} & \multicolumn{5}{|c|}{1979} \\
\hline & $\mathrm{L}$ & G & $\mathrm{E}$ & time spent & $\mathrm{L}$ & $\mathrm{G}$ & $\mathrm{E}$ & $\mathrm{H}$ & $\begin{array}{l}\text { time spent } \\
\text { (hours) }\end{array}$ \\
\hline \multicolumn{10}{|c|}{ NORDAUSTLANDET } \\
\hline Nordkapp & $\mathrm{x}$ & $x$ & & 1 & $x$ & & & & $2 t$ \\
\hline Vesle Tavleøya & $\mathrm{x}$ & $\mathrm{x}$ & & $t$ & & & & & \\
\hline Martensøya & & $\mathrm{x}$ & $\mathrm{x}$ & $t$ & $\mathrm{x}$ & & & & $1 \mathrm{t}$ \\
\hline Nelsonøya & $\mathrm{x}$ & $\mathrm{x}$ & & $t$ & & & & & \\
\hline Parryøya & & & & & $\mathrm{x}$ & & & & $1 \frac{1}{2} \mathrm{t}$ \\
\hline Phippsøya & & & & & $\mathrm{x}$ & & & & $1 \mathrm{t}$ \\
\hline Waldenøya & $\mathrm{x}$ & $x$ & & d & $\mathrm{x}$ & & & & $2 \frac{1}{2} \quad t$ \\
\hline Depotodden & $x$ & & & $t$ & $x$ & & & & $3 \mathrm{t}$ \\
\hline Goosbukta & & $x$ & & $t$ & & & & & \\
\hline Selanderneset & & & $\mathrm{x}$ & $d$ & & & & & \\
\hline Zeipelfjellet & & & & & $\mathrm{x}$ & & $x$ & & $\mathbf{t}$ \\
\hline Karl XII Oyane & $\mathrm{x}$ & & & $\mathrm{t}$ & $x$ & & & & $3 \mathrm{t}$ \\
\hline Foynøya & & $\mathrm{x}$ & & $t$ & $\mathrm{x}$ & $x$ & & & $4 \mathrm{t}$ \\
\hline Brochøya & & $\mathrm{x}$ & & $\mathrm{t}$ & $\mathrm{x}$ & $\mathrm{x}$ & $\mathrm{x}$ & & $2 \mathrm{t}$ \\
\hline Kapp Bruun & & & & & $\mathrm{x}$ & & $\mathrm{x}$ & & $3 \mathrm{t}$ \\
\hline Damhaugen & & & & & & & & $\mathrm{x}$ & $\mathrm{d}$ \\
\hline Winsnesbreen & & & & & & & & $\mathrm{x}$ & $\mathrm{d}$ \\
\hline \multicolumn{10}{|l|}{ KONGSOYA } \\
\hline Kapp Koburg & & & & & $x$ & & & & $t$ \\
\hline Sjogrenfiellet & & & & & $x$ & & & & $\mathrm{t}$ \\
\hline Cordneset & & & & & $\mathrm{x}$ & & & & $\mathrm{t}$ \\
\hline Retziustiellet & & & & & $x$ & & & & $\mathrm{t}$ \\
\hline Vorth of Rundisen & & & & & $x$ & & & & $d$ \\
\hline \multicolumn{10}{|l|}{ SPITSBERGEN } \\
\hline Geren & & $\mathrm{x}$ & & $d$ & & & & & \\
\hline Kapp Fanshawe & & & $\mathrm{x}$ & $d$ & & & & & \\
\hline Mosselbukta & & & & & $x$ & & & & 21 \\
\hline
\end{tabular}




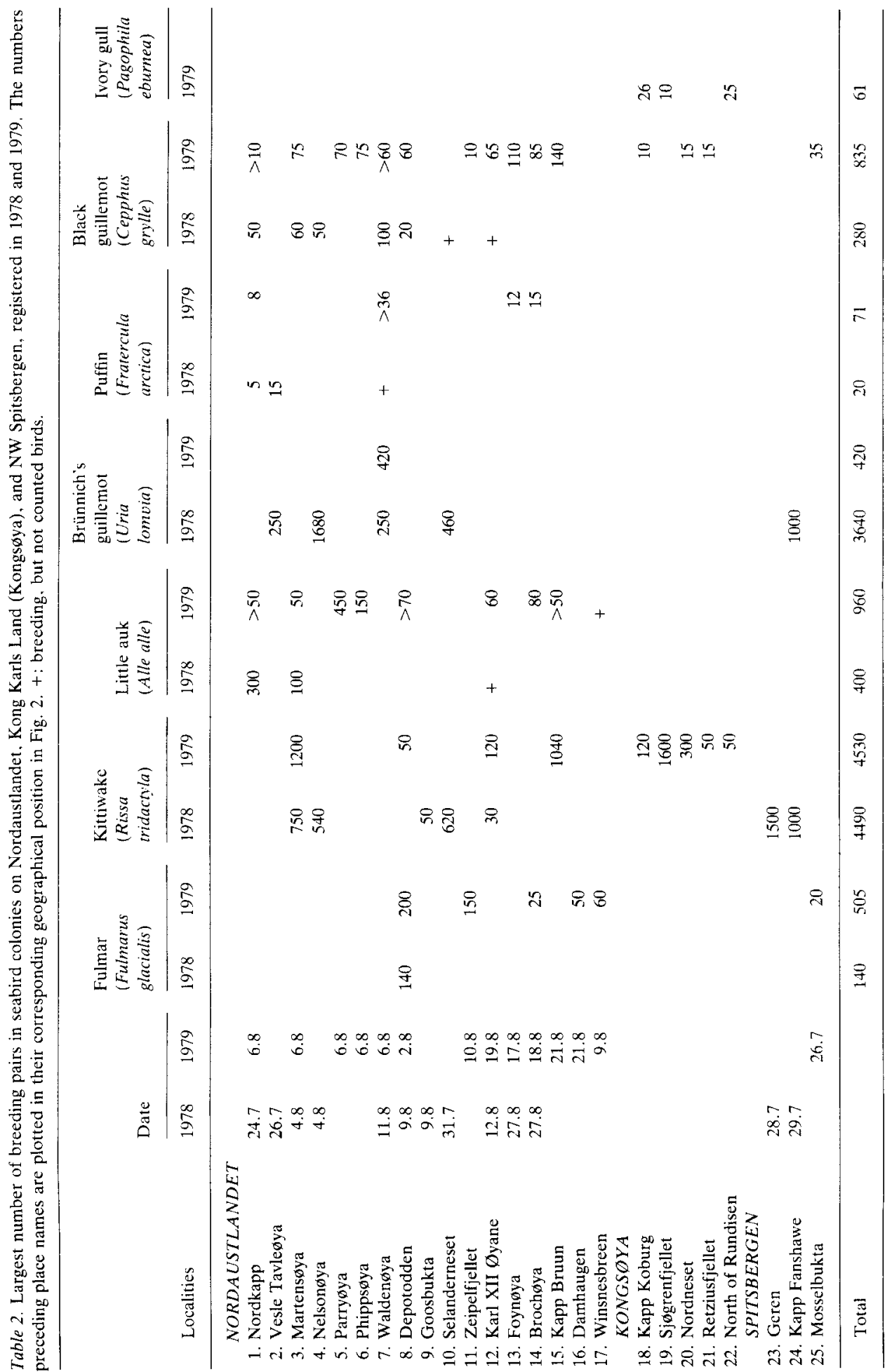


Karl XII Øvane. 19 August

Kapp Bruun. 21 August

S. Repøya, 22 August

From 12 to 25 August, H. Robak surveyed bird cliffs on Kongsøya. Several rather small bird cliffs were found in 1979 in connection with aerial surveys of eider Somateria mollissima and reindeer Rangifer tarandus plaṭrhynchus.

\section{Ice and observation conditions}

Quantitative registrations of seabird colonies in Nordaustlandet are hampered by the extreme weather conditions prevailing in the arctic regions. Some colonies could not be counted because of bad weather in 1978 and 1979. In other cases poor visibility and precipitation must be blamed for the inferior quality of a few counts.

The count at Waldenøya was difficult in 1978. and in 1979 bad weather prevented a visit to Nelsonøya.

In 1978, registrations of breeding pairs in several colonies could be made from a rubber dinghy below the cliffs. but this method could only be used to a limited extent in 1979, when solid summer ice surrounded the islands and coastline in the northwestern part of Nordaustlandet (Table 1). We therefore had to rely on helicopter transport to most localities. Such conditions may to a high degree influence the biological quality of the registrations. and make a comparison of the two years" results questionable. In addition. the time difference of the two years summer registrations at each locality also complicates the possibilities for comparative studies.

\section{Census methods}

Binoculars $(7 \times 50$ or $8 \times 40)$ and telescopes $(25 \times)$ were used for seabird registrations. Telescopes could only be used from the deck of the expedition vessel in stable weather. and for registrations on land. When registrations were made from the rubber dinghy below the bird cliffs or on land just below the cliffs, binoculars were most useful.

Both groups tried to make as exact counts as possible, but because of the large size of some colonies in relation to the registering time available. it was sometimes necessary to make counts in representative parts of the colonies only. and on the basis of these counts to estimate the total number of breeding pairs.
Each of the groups made several independent registrations both years, and these were later compared in order to find the most representative total. If the deviation between the results was too great registrations were made jointly, the observers drawing each other's attention to groups of birds or areas that might have been overlooked in the first count.

For documentation of the size of the bird colonies and the distribution of the cliffs, a sketching-in on polaroid photos was made in 1978 . This method was only used to a limited extent in 1979. when, on the other hand, drawings were used.

In both years some colonies were photographed in black/white for later registration. At a possible later selection of a representative number of colonies on Nordaustlandet for more systematic investigations, this method would supply valuable documentation material, especially for species such as kittiwake and Brünnich's guillemot.

In the field the prime objective was to locate as many seabird colonies as possible and estimate the approximate number of breeding pairs.

The method of sketching-in colonies, either on polaroid photos or on drawn sketches, will make it possible to evaluate the fluctuation pattern of some species, as the space occupied in a given cliff area will change if the populations increase or decrease in number.

The method appears to give a significant and reliable index, giving future observers a good basis for continuous studies and enabling them to estimate where it is important to concentrate investigations.

The sketching-in method might be used with reasonable certainty in size estimates of colonies of fulmars, kittiwakes, and Brünnich's guillemots, but it cannot really be used for registering little auks, puffins, or black guillemots, breeding more scattered on the cliffs.

In 1979 the observers could use the two expedition helicopters, and a total of 26 hours were spent on various biological surveys. This meant that great areas could be surveyed for breeding colonies. Real registrations are not possible and justifiable from aircraft, however, since flying in the immediate vicinity of colonies causes an unacceptable degree of disturbance. On later occasions it was possible to investigate some of the registered colonies on land.

Helicopter was also used to register breeding and moulting eiders. 


\section{Results}

\section{Seabird colonies}

Four different colonies with more than 1,000 breeding pairs were found on Nordaustlandet during the NP expeditions in 1978 and 1979, on Selanderneset and Nelsonøya in 1978 and on Martensøya and Kapp Brunn in 1979 (Fig. 2). In three of the colonies, more than 1,000 pairs of one species were breeding.

On Nelsonøya, 1,700-1,800 pairs of Brünnich's guillemot were found and on Martensøya and Kapp Bruun there were approximately 1,200 and 1,000 kittiwake pairs, respectively.

One colony of 500-1,000 pairs of seabirds was found on Martensøya in 1978, and two on Parryøya and Waldenøya in 1979.

In 1978 a colony with possibly more than 100,000 pairs was registered west of Hinlopen on the well-known Alkefjellet mountain. No real count of breeding pairs was made. Two colonies at Geren in Lomfjorden and Kapp Fanshawe on the Lomfjordhalvøya peninsula were also found to have $1,000-1,500$ pairs of kittiwake and 2,000 pairs of kittiwake/Brünnich's guillemot, respectively.

A colony of 1,500 pairs of kittiwake and several smaller colonies on Sjøgrenfjellet on Kongsøya, Kong Karls Land, were found in 1979.

Breeding pairs in seabird colonies registered in 1978 and 1979 are listed in Table 2. The numerals preceding locality names refer to geographical position (see Fig. 2).

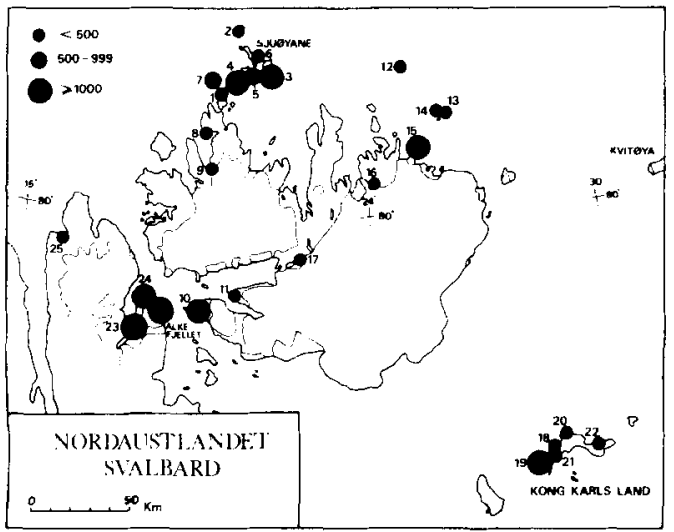

Fig. 2. Seabird colonies recorded and counted in 1978 and 1979. The colonies are shown in three size categories, and include the species mentioned in Table 2. Numbers refer to the list of localities in Table 2 .

\section{Sketches of seabird colonies on Nordaustlandet}

The positions of the various seabird species on the cliffs are shown in Figs. 3-10. Only localities where it has been possible to sketch in the extent of the colonies are shown. The size of the colonies has been sketched-in on three cliffs both in 1978 and 1979.

For future registrations of the cliffs visited in 1978 and 1979 , it is possible with advantage to draw up sketches of some other areas, e.g. Parryøya, Phippsøya, and Waldenøya. There the colonies are found concentrated in well-defined cliff areas. In other areas, however, the birds breed very sparsely, for instance at Foynøya, Brochøya, and in two localities on Kongsøya. In these cases sketches would hardly be of much help. In Figs. 12 and 16 for respectively fulmars and black guillemots, some colonies appear with an arrow. These colonies were registered from helicopter in 1979 , but no real count was made.

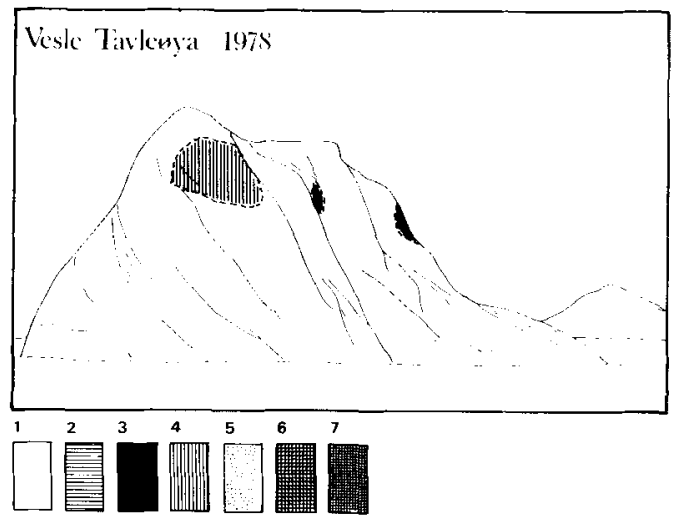

Fig. 3. Northwest side of Vesle Tavleøya with seabird colonies sketched in. Legend (refers to Figs. 3-5 and 7-10): - - colonies counted in 1978, - - colonies counted in 1979. 1. Fulmar Fulmarus glacialis, 2. Kittiwake Rissa tridactyla, 3. Little auk Alle alle, 4. Brünnich's guillemot Uria lomvia, 5. Black guillemot Cepphus grylle, 6. mixed colonies of nos. 2 and 4, 7 . mixed colonies of nos. 3 and 5 .

Vesle Tavleøya (Fig. 3) is an island in the Sjuøyane group and, together with Ross $\varnothing y a$, is Svalbard's northernmost island at almost $81^{\circ} \mathrm{N}$. Brünnich's guillemot is dominant among the breeding birds, and the colony is found at the northwestern corner of the island, opposite Rossøya. On the west side of the island a few little auks and black guillemots are found breeding, together with the rather small colony of puffins. The colony was counted in 1978. 


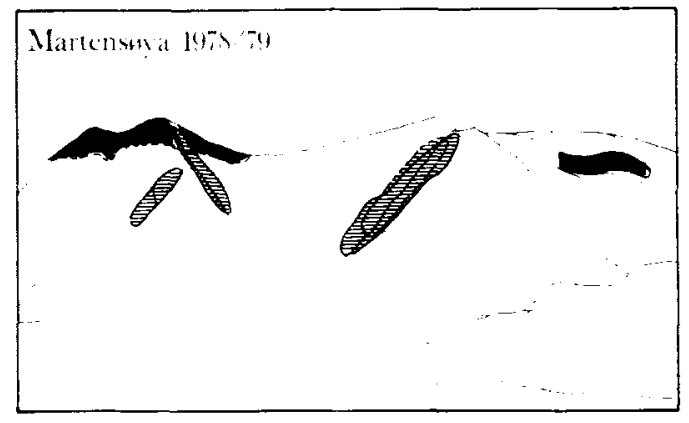

Fig. 4. Martensøya observed from the southeast with seabird colonies sketched in. For legend, see Fig. 3

Martensøya (Fig. 4) is the easternmost island in the Sjuøyane group, located at approximately $80^{\circ} 40^{\prime} \mathrm{N}$. The seabird colonies are found on the south-southeast side of Sølvberget, where the kittiwake is represented in the largest numbers. Little auks, black guillemots, and puffins breed sparsely. The colonies were counted both in 1978 and 1979.

Nelsonøya (Fig. 5) is one of the smallest islands in the Sjuøyane group lying 200-300 metres southwest of Parryøya. The island has two rather large seabird colonies containing the largest registered concentrations of breeding Brünnich's guillemots on Nordaustlandet. In addition, a rather large colony of kittiwakes and a rather small population of black guillemots and puffins are found. The colonies are found on the north and northwest sides (Fig. 5B) and on the south side of the island. On the sketch (Fig. 5A) showing the south side of the island, the Brünnich's guillemots area is indicated rather inaccurately, because the birds appear extremely concentrated on clear. vertical geological layers in the cliff. On the west side of

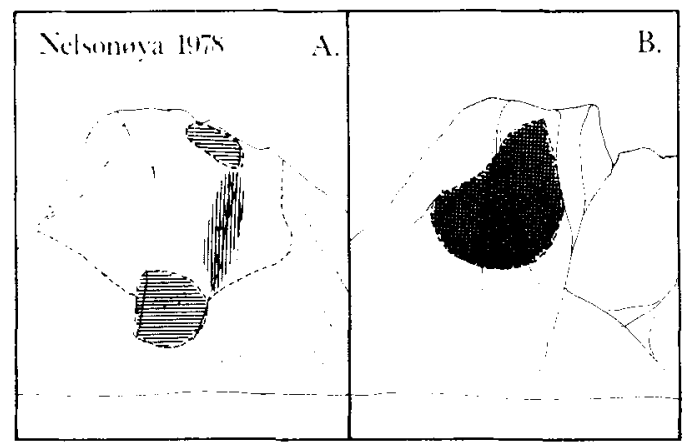

Fig. 5. Nelsonøya observed from the south (A), and the north (B). with seabird colonies sketched in. On the southern cliff Brünnich's guillemots were found scattered over the dashed line. but concentrated around vertical crevices (shaded areas). For legend, see Fig. 3.

the island the birds were breeding very sparsely, making it difficult to sketch-in the colonies accurately. They have therefore been left out. The colonies were counted in 1978.

Depotodden (Figs. 6 and 7) is situated in the western part of Laponiahalvøya (approximately $\left.80^{\circ} 20^{\prime} \mathrm{N}\right)$. The seabird colonies are found on the steep cliffs facing south. The only colony of fulmars registered on Nordaustlandet in 1978 was found here, and it also showed the highest number of breeding pairs among the few colonies registered in 1979. Both years the colony was found on the cliff north of the cottage. In 1979 a rather small colony of kittiwakes was found on the cliff together with breeding little auks. A small number of black guillemots were observed breeding both in 1978 an 1979, little auks and black guillemots were found scattered on the cliff, and their breeding areas are therefore difficult to sketch-in on the map.

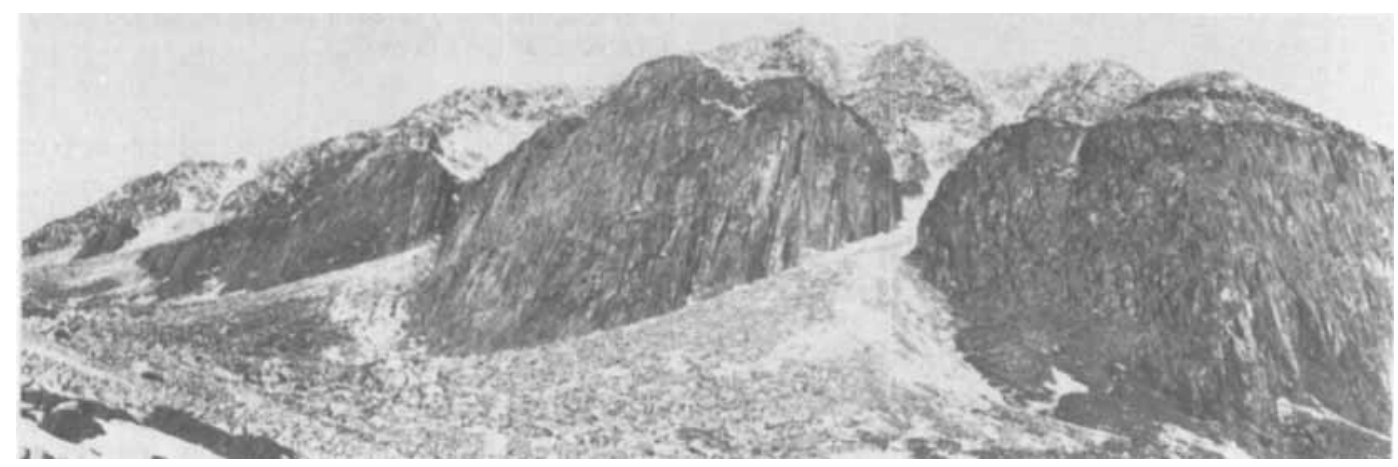

Fig. 6. Depotodden. 2 August 1979. Compare with sketch in Fig. 7. Photo: Palle Uhd Jepsen. 


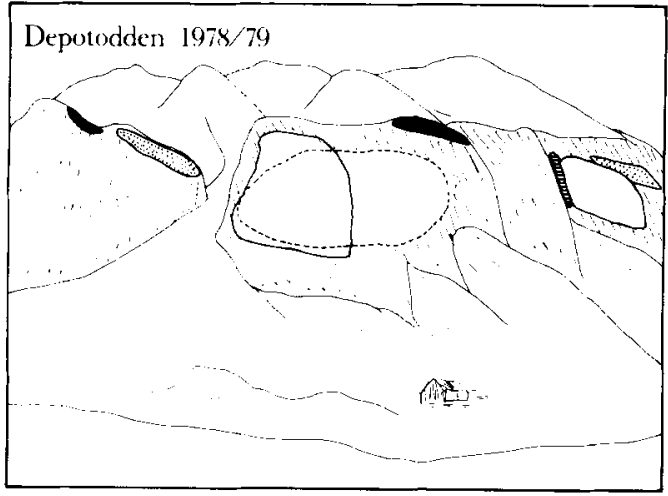

Fig. 7. Depotodden with seabird colonies sketched in. Fulmars were breeding scattered in the colonies. For legend, see Fig. 3. See also Fig. 6.

Selanderneset (Fig. 8) is the name of the northwestern corner of Scaniahalvøya at the mouth of Wahlenbergfjorden (approximately $79^{\circ} 35^{\prime} \mathrm{N}$ ). The seabird colonies are found southwest of the foreland opposite Hinlopen. Colonies of Brünnich's guillemots and kittiwakes were found in 1978 totalling more than 1,000 pairs. A few black guillemots were also registered. The localities were not visited in 1979.

Karl XII Øyane (Fig. 9) are two islands north of eastern Nordaustlandet at approximately $80^{\circ} 35^{\prime} \mathrm{N}$. They are connected by a high beach ridge consisting of stone and very coarse-grained gravel. The southern cliff of the northern island has a very lush moss vegetation on the lower eroded slope. A colony of kittiwakes was registered there both in 1978 and 1979 totalling 30 and 120 pairs, respectively. Both the southern and northern islands have populations of black guillemots. The little auk breeds on the northern island and at least two pairs were registered in 1979.

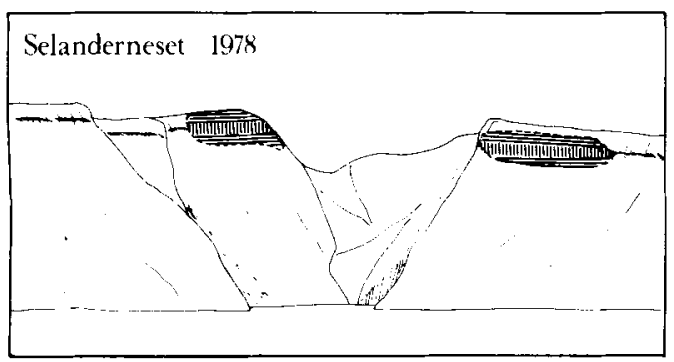

Fig. 8. Southwest side of Selanderneset with seabird colonies sketched in. For legend, see Fig. 3.

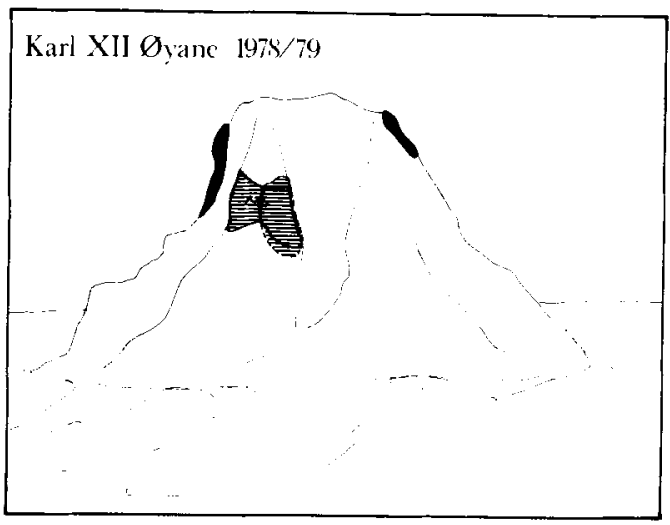

Fig. 9. Karl XII Øyane seen from the southeast with seabird colonies sketched in. For legend, see Fig. 3.

Kapp Bruun (Fig. 10) is the northernmost cliff massif on a peninsula in the northeastern part of Nordaustlandet, east of Prins Oscars Land. The seabird colonies are found on a steep cliff at approximately $80^{\circ} 16^{\prime} \mathrm{N}$. In 1979 more than 1,000 pairs of kittiwakes were found breeding in four small colonies, and a well-defined colony of about 60 pairs of black guillemots. In addition, approximately 80 pairs of black guillemots were breeding scattered on the cliff. The little auk was breeding in small numbers.

\section{The seabirds}

The following is a description of the breeding occurrence of seabirds in the areas investigated in 1978 and 1979 . The survey is hardly satisfactory, however, as there are probably still some unknown colonies. In 1979 large areas in the northern and western parts of Nordaustlandet (Fig. 1) were surveyed by helicopter in connection with other registrations, without discovery of any big seabird colonies (see Table 1).

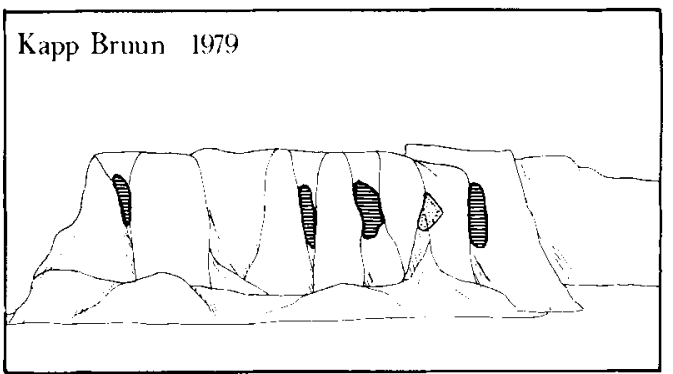

Fig. 10. North side of Kapp Bruun with seabird colonies sketched in. For legend, see Fig. 3. 


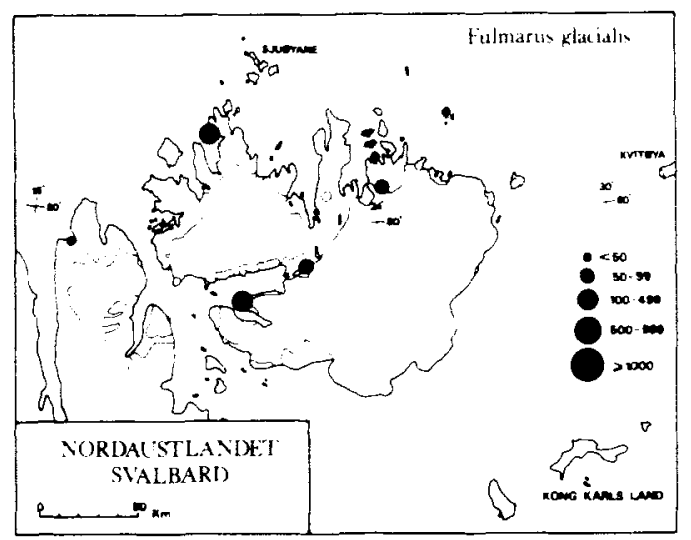

Fig. 11. Colonies of fulmars shown as the greatest number of breeding pairs counted in 1978 and 1979. The colony marked with arrows was surveyed from helicopter in 1979 and is not included in Table 2

Fulmar Fulmarus glacialis (Fig. 11). - The greatest colony on Nordaustlandet was registered on Depotodden, where the number of breeding pairs was estimated at 140 in 1978 and approximately 200 in 1979. On Zeipelfjellet in Palanderbukta, 100-150 pairs of fulmars were counted in 1979 ( $\varnothing$. Lauritzen pers. comm.).

The most remarkable discoveries of breeding fulmar colonies were at Damhaugen and Winsnesbreen in 1979, with respectively 50 and 60 pairs. The colonies were situated respectively 15 and $12 \mathrm{~km}$ from the nearest coast, and were registered from helicopter.

Discovery of breeding fulmars at inland localities, e.g. on nunataks, is also mentioned by Norderhaug et al. (1977). No breeding fulmars were

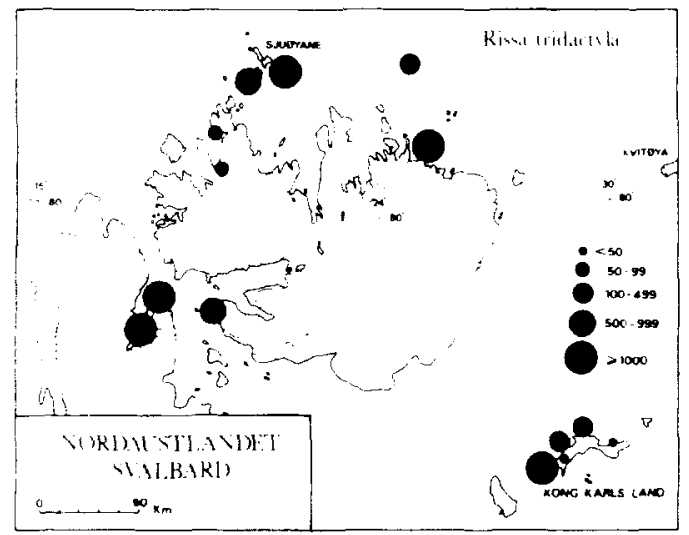

Fig. 12. Colonies of kittiwakes shown as the grcatest number of breeding pairs recorded in 1978 and 1979. found in the seabird colonies on Kong Karls Land and Spitsbergen, marked in Fig. 2.

Kittiwake Rissa tridactyla (Fig. 12). - The northern-most seabird colony in Svalbard was registered on Martensøya, with the highest number of breeding pairs on Nordaustlandet in 1979, viz. 1,200 . In 1978 the breeding population here totalled $700-750$ pairs.

Breeding kittiwakes registered on Nelsonøya in 1978 numbered $480-540$ and were distributed in three colonies. The largest colony, with $350-$ 400 pairs, was discovered on the south side of the island. This locality was not visited in 1979. In addition small colonies were found in Goosbukta and on Depotodden. A colony of more than 600 pairs was found on Selanderneset in 1978.

The Kapp Bruun colony is the second largest discovered on Nordaustlandet in 1979 with 1,040 breeding pairs. The colony was counted on 21 August, at which time most of the juvenile birds were close to fledging. Some had already left the cliff, as juvenile birds could be watched from the vessel. A colony of 120 pairs on Karl XII Øyane visited on 19 August had fledged juvenile birds in the colony. It was also visited in 1978 , when about 30 pairs were registered.

The total number of breeding pairs registered on Nordaustlandet in 1978 was just under 2,000, and in $1979,2,400$ pairs. In 1979 more than 2,000 pairs were counted on Kong Karls Land (Kongsøya), distributed in five colonies, the largest having 1,600 pairs.

Little auk Alle alle (Fig. 13). - Breeding little auks were found in greater or smaller numbers

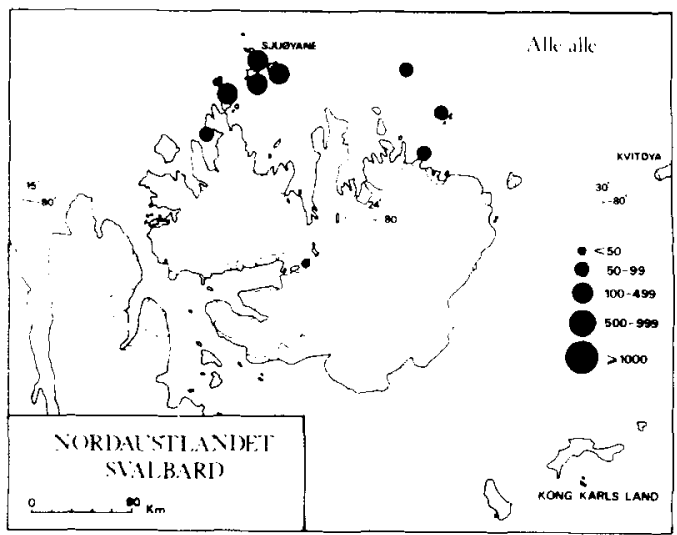

Fig. 13. Colonies of litule auks shown as the greatest number of breeding pairs in 1978 and 1979. 


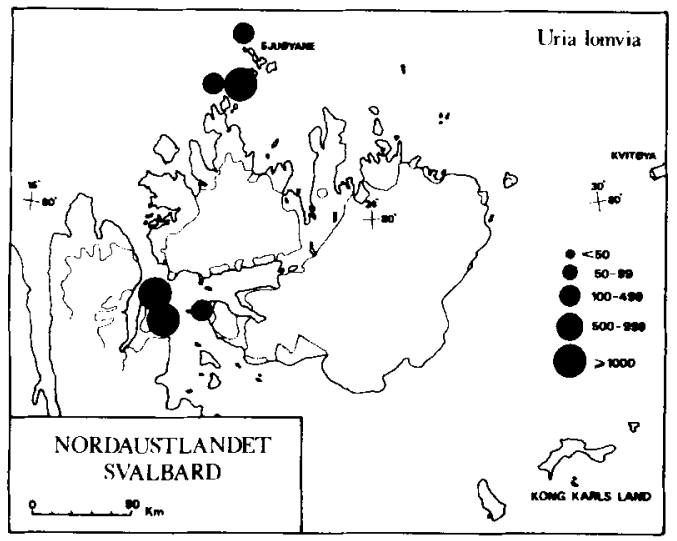

Fig. 14. Colonies of Brünich's guillemots shown as the greatest number of breeding pairs in 1978 and 1979.

in practically all investigated seabird cliffs. In addition, the species bred alone in small numbers at many localities; this was noticed during the helicopter survey in 1979. It is often difficult to estimate the exact number of breeding little auks in colonies. The birds breed scattered, and the nests are often found at the tops of cliffs in the most inaccessible places. The number of breeding pairs in the various colonies are therefore given with certain reservations, and should be regarded as absolute minimum numbers.

In 1978, the largest colony of breeding little auks was registered on Nordkapp, 250-300 pairs. Fifty pairs were counted in the same place in 1979 , but this small figure is probably due to the fact that there was very little time available for counting that year. The real number must certainly be much higher, judging from the great number of little auks seen flying near the colony. One flight, for instance, had approximately 200 individuals. In 1979 the largest rolony of little auks was found on Parryøya, with about 450 breeding pairs. No breeding little auks were discovered during the surveys of Kongsøya.

Brünnich's guillemot Uria lomvia (Figs. 14 and 15). - Only a few, but big colonies were found on Nordaustlandet. The highest number of breeding pairs was registered on Sjuøyane in 1978, where Nelsonøya alone counted three different colonies totalling 1,680 pairs. In addition, 250 pairs were counted in a colony on Vesle Tavleøya. These two islands were not visited in 1979, when a colony of 100 pairs was found on Depotodden. Approximately 250 pairs were breeding on

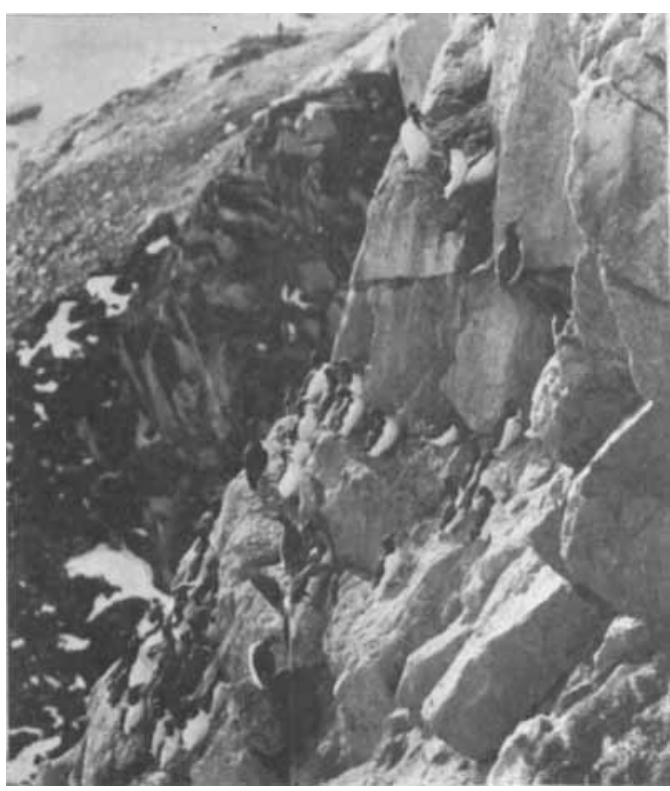

Fig. 15. Colony of Brünnich's guillemots on Waldenøya, 6 August 1979. Photo: Palle Uhd Jepsen.

Waldenøya in 1978 , and more than 400 pairs in 1979.

In 1978 a colony of 600 pairs of Brünnich's guillemots was found on Selanderneset in Waldenbergfjorden. This area was not visited in 1979.

On Spitsbergen a mixed colony of kittiwakes and Brünnich's guillemots was found in 1978. A total of 2,000 pairs were found on Kapp Fanshawe. As previously mentioned, the large colony on Alkefjellet (Løvenskiold 1964) was registered too, probably also including a considerable population of Brünnich's guillemots.

No Brünnich's guillemots were recorded on Kongsøya in 1979.

A total of 2,640 and over 500 breeding pairs were registered on Nordaustlandet in 1978 and 1979 , respectively. The figures cannot be directly compared, however, because parts of Sjuøyane were not visited in 1979.

The choice of nesting site in relation to the geological structure of the cliff is significant for the Brünnich's guillemot. This was particularly clearly observed at Selanderneset in 1978, where the nests were always placed on shelves of horizontal, sedimentary rocks (Fig. 8).

Puffin Fratercula arctica. - This bird breeds very sparsely at Nordaustlandet. The largest total number of pairs was found on Waldenøya in 1979, 


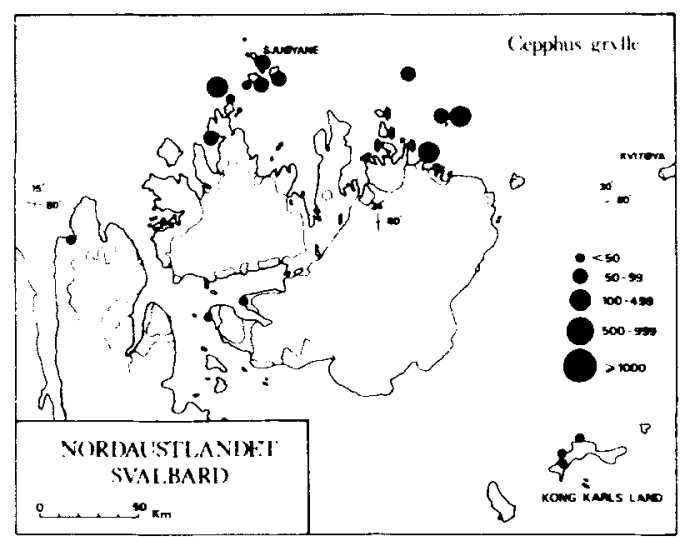

Fig. 16. Colonies of black guillemots shown as the greatest number of breeding pairs counted in 1978 and 1979. Colonies marked with arrows were surveyed from helicopter in 1979 and are not included in Table 2.

where the breeding population was estimated at minimum 36 pairs. In addition, the species was found scattered in small quantities on other islands, among others on Vesle Tavleøya.

The species was not observed on Kongsøya in 1979.

Black guillemot Cepphus grylle (Fig. 16). - This bird only breeds in small colonies on Nordaustlandet and on Kongsøya, most often together with other species. The black guillemot does not always breed in well-defined colonies, but the nests are sometimes seen scattered on the cliffs. Several small colonies of black guillemots, with no other species breeding in the immediate vicinity, were observed during aerial surveys along the coasts around Prins Oscars Land, Glenhalvøya,

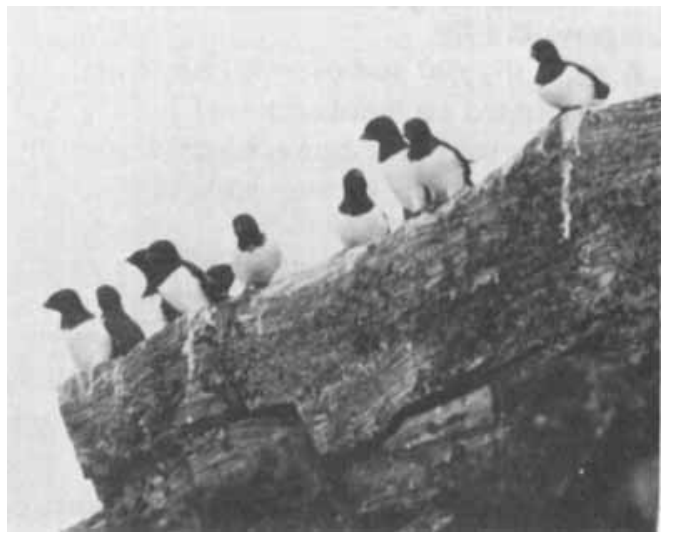

Fig. 17. Little auks on Karl XII Øyane, 19 August 1979. Photo: Palle Uhd Jepsen and Repøyane in 1979. Because of the very limited occurrence of breeding black guillemots, the count figures from the two years must be taken as absolute minima.

At Nordaustlandet a little less than 300 pairs were recorded in 1978, and 1,100 pairs in 1979. The great difference is first and foremost due to higher aerial survey results in 1979. On Kongsøya approximately 40 pairs of black guillemots were recorded in 1979.

Glacuous gull Larus hyperboreus. - This bird breeds scattered on Nordaustlandet, and also occurs on Kongsøya. It is found mainly in the immediate vicinity of other seabird colonies. The largest number of pairs recorded within a welldefined area was six pairs in 1979; a total of 40 pairs were counted in connection with seabird colony surveys.

Ivory gull Pagophila eburnea. - This bird was not observed breeding on Nordaustlandet in 1978 and 1979 , but on Kongsøya five rather small colonies totalling more than fifty pairs were recorded in 1979. Eight pulli were caught and ringed. According to Løvenskiold (1964) ivory gulls breed on Storøya and Kvitøya, but the species was not recorded at these localities in 1978 and 1979. Ahlmann \& Malmberg (1931) also mention that the ivory gull is a common breeding bird on Kvitøya.

The species is quite widespread in areas with drifting ice around Nordaustlandet, and in 1978 and 1979 more than ten individuals were observed several times a day when the expedition vessel passed through ice covered waters.

\section{Discussion}

This report is one of several contributions describing the bird-life in these arctic regions and, to a limited extent, comparing the population sizes by observing the same colonies in two successive years. It has been mentioned that the figures for some species, first of all for the little auk, black guillemot, and puffin, must be regarded as absolute minima, as it is difficult to produce exact figures for birds breeding scattered and in impassable mountain regions. Undiscovered seabird colonies probably exist along the coast of Nordenskiöldbukta, Rijpfjorden, and Duvefjorden. In addition, some seabird colonies have probably been overlooked in Wahlenbergfjorden. 
The rather different recording methods used in 1978 and 1979, mainly because of the greater extention of solid ice in 1979 compared with the year before, may complicate a direct comparison of the numbers of breeding pairs in colonies visited and recorded both years. When counting from a boat below a cliff, the size of the breeding population will often be underestimated. This is especially so in the case of breeding Brünnich's guillemots and fulmars, where some birds are hidden behind others or are sitting so far in on the shelves, that they escape notice.

Counts made from the mountain top on the other hand will be impeded by a poorer general view and will also cause some disturbances in the colonies. But, if plenty of time is available, the method will probably give good information of the number of breeding pairs present. The two methods may profitably be combined, if circumstances permit.

Norderhaug (1974) points to the possibility of recording nonbreeding individuals as breeding pairs in the seabird colonies. This risk must absolutely be taken into consideration.

Counts after the middle of August, when birds start to leave the colonies (Norderhaug et al. 1977), can also give a wrong impression of population size.

The largest seabird colonies in Svalbard are found in the western part of the archipelago, where the favourable influence of the Gulf Stream on the climate and biological production forms the basis of the, for arctic regions, extremely high density in the breeding seabird populations.

Farther east, around Nordaustlandet, the summer sea temperature decreases to under $0^{\circ} \mathrm{C}$ compared to $2.5-3^{\circ} \mathrm{C}$ west of Spitsbergen (Løvenskiold 1964). This must to a high degree influence the ecological conditions for the birds, and be one of the reasons for the relatively lower number of breeding pairs here. Great annual variations in the distribution of solid ice around
Nordaustlandet must also influence breeding success and thus cause great, annual fluctuations in the number of breeding pairs in the colonies.

To get more information on these questions, it is important that the counts started be supplemented with breeding biology studies, including production analyses, mortality studies, and investigations of the food supply available.

The development of new methods for estimating breeding populations more exactly should be encouraged. With this end in view, small seabird cliffs with less than 1,000 pairs can be chosen, which may be counted with reasonably great accuracy. Counts should be made several times during 24-hour periods over a fairly lengthy period of time to ascertain day and night variations caused by the activity pattern of the birds, the weather, temperature, etc. (Norderhaug 1980 ).

The accuracy of counts is reduced the larger the size and the higher the density of colonies; selected colonies must therefore be frequently photographed in order to provide reference material and documentation.

\section{References}

Ahlmann. H. W. \& Malmberg, S. 1931: Sommar vid Polhavet Stockholm. $301 \mathrm{pp}$

Larsen. T. 1965: Ornitologiske undersøkelser fra den nordvestre del av Vestspitsbergen sommeren 1967. Norsk Polarinst. Arbok 1963, 259-263.

Løvenskiold, H. L. 1964: Avifauna Svalbardensis. Norsk Polarinst. Skrifter No. $129,460 \mathrm{pp}$.

Norderhaug, M. 1967: Trekkforhold, stredstrohet og pardannelse hos alkekonge på Svalbard. Fauna 20(4), 236-244.

Norderhaug, M. 1974: Studier av sjøfuglkoloniene på Fuglehuken, Prins Karls Forland Nasjonalpark. Norsk Polarinst. Árbok 1972, 99-106.

Norderhaug, M., Brun, G. \& Möllen, G. U. 1977: Barentshavets sjøfuglressurser. Norsk Polarinst. Medd. No. $104,119 \mathrm{pp}$

Norderhaug, M. 1980: Breeding biology of the Little Auk (Plautus alle) in Svalbard. Norsk Polarinst. Skrifter No. 173. 45 pp. 
